\title{
JAVASLATOK A TANÁRKÉPZÉS \\ ÁL- ÉS VALÓS PROBLÉMÁK HALÓJÁBÓL VALÓ KISZABADÍTÁSÁHOZ
}

\section{GÁSPÁR MIHÁLY}

\author{
a Nyugat-Magyarországi Egyetem Bölcsészettudományi Karának \\ tanszékvezetö föiskolai tanára \\ psych@deimos.bdtf.hu
}

A pedagógusképzésben résztvevők közösségében huzamosabb ideje jelentős feszültségek mutatkoznak, az elhúzódó belső viták mellett a képzési piac újraosztása komoly energiákat köt le. Mindeközben a pedagógusok és a pedagógusképzés társadalmi presztízse, fontosság érzése, elismertsége régen nem látott mélységekbe került. A pedagógusok, a közoktatás résztvevőinek méltatlan helyzete az ország jövőjét is alapvetően veszélyezteti.

Ezt a közös érdeket természetesen a vitatkozó felek mindegyike ismeri, és elismeri, de úgy tünik, a rövidtávú érdekek erösebbnek bizonyulnak. Sokan fontosabbnak látják ugyanakkor a belső harcot, mint a helyzet általános javítása érdekében történő közös fellépést. Meglátásom szerint az élesedő vita eltereli a figyelmet a fontosabb, kormányzati lépéseket igénylő feladatról.

A vita lényege abból táplálkozik, hogy a tanárképzés rendje, logikája, tartalma jelentősen megváltozott a bolognai-rendszer bevezetése következtében. A változás - mint minden érdemi változás - valós és vélt érdekeket egyaránt sértettek. Érdekes módon a változást erösen ellenzők között a nagy egyetemek, illetve a természettudományok reprezentánsainak a hangja a legerősebb. Fellelhető ebben a régröl ismert egyetemek-föiskolák ellentéte is, de ezt már inkább csak mellékes problémának látják. A valódi szembenállást a pedagogikum és a diszciplínák érdekeinek látszólagos ellentéte váltotta ki. Azért nevezhetjük látszólagos ellentétnek, mert meglátásunk szerint a tanárképzésben a két terület egymásra van utalva, és az öszszetartozót szétválasztani, sőt szembeállítani nem szerencsés.

De hogyan alakulhatott ki ez az indokolhatatlan szétválasztás és szembeállítás? A Nemzeti Bologna Bizottság Pedagógusképző Albizottsága volt hivatott arra, hogy a tanárképzés új rendszerének szakmai vitáját levezesse, és kialakítsa az új képzési struktúrára vonatkozó javaslatot. A vita ugyan nem volt feszültségmentes, de a közoktatás képviselői lényegében egyértelmúen állást foglaltak a változtatás fő irányának meghatározásában. Eszerint a közoktatás nem volt elégedetlen a tanárok szaktudományos felkészültségével, azonban a tanári mesterség általános kö- 
vetelményeiben nyújtott teljesítményük terén fejlődést, fejlesztést tartottak szükségesnek. A hatékonyság növelésének egyik fókuszában a tanulókkal, szülőkkel folytatott interakciók állnak, mivel a pedagógusok nem mindig találják meg a megfelelő eszközt, módszert, attitüdöt az iskolai szituációk színes palettájának optimális kezeléséhez. Leegyszerüsítve és egy szegmensre koncentrálva a probléma nem az, hogy a földrajz tanár ne tudná, hol folyik a Nílus, sokkal inkább az, hogy nem tudja elérni a gyerekeknél, hogy ők is fontos kérdésnek tekintsék, és ezért megtanulják.

A közoktatás erős igénye alakította ki tehát a tanárképzés új rendszerének azt a jellegzetességét, hogy a tanári mesterség általános kompetenciáit állítsuk a követelmények középpontjába. Nemzetközi és hazai tapasztalatokat is összesítve kialakítható volt a tanári mesterség eredményes gyakorlásához szükséges általános kompetenciák értelmezése, rendszerezése és rögzítése. Ebben hangsúlyosan szerepet kap ugyan a magas szintủ szaktudományos felkészültség követelménye is, de a korábbi logikával szemben nem ez a kizárólagosan vezető szempont. Az új logika rögzíti tehát: a tanári mesterségnek egy a szaktudományos háttértől nem független, de attól jól elkülöníthető követelményrendszere is van, létezik egy a szaktól elkülöníthető képességstruktúra, amit a tanári professzió általános részének tekinthettünk. Ezt elfogadva célszerünek látszott ezt a képzési feladatot az új rendszer középpontjába állítani a pedagógus mesterség hatékonyságnövelésének érdekében. Ez a lépés presztízssérelmet okozhatott a korábbi középpont - a diszciplínák - képviselői számára. Hangsúlyozzuk, hogy meglátásunk szerint ez nem érdek, hanem csak presztízssérelem, mert kimutatható, hogy a diszciplínák érdeke az új rendszerben tényszerủen nem sérült. Erre később kitérünk.

Létrejött tehát az egységes és mester szintü tanárképzés, ahol a megfelelő szintű szaktudományos felkészítés döntő mértékben az alapképzésre hárul. A mesterképzés középpontjába pedig a jól értelmezhető pedagógiai kompetenciák kerültek. Ebből a logikából következően a képzésért felelős szakembereket is a közös területről a pedagogikum képviselői közül volt célszerü kiválasztani. Ez újabb presztízssérelmet váltott ki: „Hogyan lehet, hogy például a biológiai tanár képzéséért nem a biológia professzora a felelös?"

Az új képzési rend ellenzői egyre több és ezzel együtt sajnos egyre inkább erőltetettnek látszó érveket sorakoztattak fel. A megjelölt fő problémák közül néhányat megemlítünk, amelyekre reflektálunk is:

1. Az új rendszer egyszerủen nem jó, mert a régi föiskolai szintü tanárképzés szintjére süllyeszti a képzés színvonalát.

2. Értelmezhetetlen az egységes tanárképzés, mert nincs általában tanár, csak biológia, magyar, földrajz stb. tanár létezik.

3. Nem lesz elegendő tanár, mert ez a képzési struktúra inkább elriasztja a hallgatókat a tanári pályától. Különösen igaz ez a természettudományok területén. 
Felmerül még az alkalmassági kritériumok felállítása, a képzési idő, a másfél szak problémája, és a tudós tanár hiánya. Különösen erős, részben szerintünk is jogos kritika éri az úgynevezett két féléves kiegészítő képzést, ami a korábbi főiskolai szintü tanári képzettséget két félév alatt emeli MA szintüre.

Nem térünk ki minden lényegesnek látszó problémára, de a vita egy jellegzetessége feltűnő. Egyre inkább a „süketek párbeszédére” hasonlít a polémia, ami azt jelenti, hogy nem egymásra reagálnak, hanem a saját érveiket ismétlik a vitapartnerek. A vitának ezt a jellegzetességét neveztem többször is unalmasnak. A konstruktív megoldások megtalálása igényelné az egymásra figyelést.

Visszatérve a három kiemelt problémára, vegyük sorra, hogy milyen tényszerü válaszok adhatók.

1. Az elsö, talán leggyakrabban elhangzó probléma, hogy a bolognai-rendszerben képzett tanárok nem kapnak megfelelö szaktudományos felkészitést, tehát a szinvonal nem lehet megfelelö!

Ez az állítás így általánosítva egyszerüen nem igaz. Az állítás értelmezésében nyilvánvalóan tényeket kell felsorakoztatni. A tények pedig azt mutatják, hogy egy tanári végzettség mögött legalább három különböző szintü szaktudományos felkészültség lehet. Egyrészt a sokat emlegetett második szakképzettség, ami az alapképzésben 50 és hozzá a mesterképzésben, a szakmódszertant nem számítva, további 30-40 kreditnyi szaktudományos teljesítményt vár el. Ez valóban megfelel a régi föiskolai szintü képzés kreditmennyiségének. A szaktudományos felkészültségben a következö, és lényegében gyakoribb eset az első szak, ami áll az alapképzés minimum 110 és a mesterképzés további 20-30 kreditjéből. Ez valamivel magasabb, mint régi egyetemi szintủ kétszakos tanári szak szaktudományos követelménye. Mindezek után meg kell említeni, hogy a rendszer lehetővé teszi, és valószínü élnek is majd vele, hogy diszciplináris mesterszak után szerezzen valaki tanári képesítést. Ebben az esetben a szaktudományos kreditszám jóval meghaladja a 200at. Általában tehát azt mondhatjuk, hogy bár eltérő szintủ szaktudományos képzettségek állnak a tanári végzettség mögött, de többségében eléri, sőt meg is haladhatja a korábbi egyetemi szintủ szaktudományos követelményeket. Ugyanakkor meg kell állapítani, hogy a tényleges probléma is található a három különböző szint értelmezésében. Nevezetesen az, hogy a tanári végzettség mögött meglévő szaktudományi alap különbözőségeit nem minősíti a rendszer különbözőnek. A felhasználóknak, az iskoláknak tehát nem elég a végzettséget igazoló oklevelet megismerni, érdemes elkérni a diploma mellékletét is, amiben a jelentős különbségek megláthatók. Természetesnek látjuk, hogy az iskolák megfelelő tájékoztatása ezt a helyzetet tisztázza. A kérdés értelmezését nem bonyolítjuk azzal, hogy vajon ugyanolyan mesterszintü szaktudományos felkészültség kell-e minden iskolában és minden életkorban. Ezzel azért nem foglalkozunk bővebben, mert elfogadjuk, hogy a magasabb szintü 
szaktudományos felkészültség a tanári képzettség általános szintjét is emeli. Azt azonban tényekkel támasztottuk alá, hogy a jelenlegi rendszer nem követel általában kevesebbet a szaktudományok területén sem.

2. A másodikként felsorolt probléma a tanári professziónak az oktatott ismeretektöl függetlenül is értelmezhetö tartalmát kérdöjelezi meg.

Ez az állítás már nem unalmassá, hanem lehetetlenné teszi az érdemi vitát. Tagadni azt az evidenciát, miszerint az emberek, a közösségek megismerése, a kommunikációs képességek, az emberekkel való bánni tudás, a közösségek fejlesztésével kapcsolatos képességek önnálóan nem is léteznek, hát legalábbis tájékozatlanságra vall. Az elfogadható, hogy a szaktudományokkal együtt értelmezhető jól a tanári professzió. Ugyanakkor ezt a kapcsolatot nem lehet leegyszerüsíteni arra, hogy „persze azért pedagógiára és pszichológiára és módszertani ismeretekre is szükség van", mert ezzel éppen a közoktatás gyakorlati tapasztalatait negligáljuk. Nem célszerü tehát azt állítani, hogy aki „,csak” az emberekhez ért magas szinten - pedagógiai pszichológiai felkészültsége révén -, az nem alkalmas a tanárképzés felelősségének az elvállalására. Ez az állítás ugyanis azt is jelenti, hogy pl. a biológia professzora alkalmas a tanárképzés vezetésére, mert biztosan ért annyira az emberekhez is, amennyire kell. Ez az aszimmetrikus szembeállítás nem vezet konstruktív megoldáshoz. A kijelentés tehát nehezen védhető. Ha még is érteni akarjuk, akkor oda jutunk, hogy a korábbi rendszer jó volt, mert a biológia tanárokat a biológusok felelössége mellett képezték. Presztízssérelmet sejtünk a háttérben, és elfogadjuk, hogy ez valódi sérelem, de akkor erröl kell beszélni!

Az eddig elemzett két problémára adott választ egymás mellé állítva új megvilágítást kap az egységes MA szintü tanárképzést elutasítók motivációja. Eszerint, bár nem igaz, hogy kevesebb szaktudományos képzést kapnak a leendő tanárok, de mivel nem a szaktudományok képviselői adják a szakfelelőst, és a pedagogikum a korábbi kereteit kibővítette, ezt nehéz elfogadni.

3. Érdekes eredményre jutunk akkor is, ha a harmadik kiemelt problémát próbáljuk tényekkel alátámasztani. Tény, hogy a természettudományok iránt és ezen belül a tanári szak iránt is a kétciklusú tanárképzés bevezetése óta tovább csökkent az érdeklödés. De az is tény, hogy ez a csökkenés nem hazai jelenség és nem is az új típusú tanárképzés bevezetésével kezdödött. Kétséges tehát oksági kapcsolatot feltételezni ott ahol az okozat elöbb jelentkezett, mint az ok!

Sajnos a helyzet tényleg drámai, nem lehet a kezünket széttárva tehetetlenül szemlélni, hogy néhány év múlva nem lesz tanár fizikából, kémiából vagy bármely más tantárgyakból sem. Sürgetően intézkedni kell tehát, hogy mielőbb értelmét lássák az arra alkalmas fiatalok a tanári pálya választásának. Ennek érdekében el lehet 
rendelni, hogy a tanárképzés esetében állítsuk vissza a korábbi képzési rendet, azonban a visszaállítás nem fogja javítani a tanári pálya vonzerejét. Meglátásunk szerint ugyanis az új többciklusú felsőoktatás csak láthatóbbá tette és nem előidézte a tanárképzés valódi problémáját, a tanári pálya elképesztően alacsony társadalmi megbecsülését.

A korábbi rendszerben csak igen korlátozott számban képeztünk a mai értelemben vett diszciplináris mester szakosokat, továbbá az egyetemi szintű tanári végzettség a szaktudományok doktori képzésébe is adhatott belépőt. Ennek megfelelően viszonylag „tömeges” volt a tanárképzés, bár a végzett tanárok nagy hányada nem került a tanári pályára. Az így kialakult helyzetnek volt köszönhető, hogy a korábbi tanárszakokon a pedagogikum másodrangú képzési terület volt, hiszen úgysem tanárnak készül a többség. Ez a hangsúlyeltolódás különösen az egyetemeken volt kifejezettebb, hiszen a főiskolák tanár szakosai közül sokan jobb híján kerültek „csak” föiskolára, és nagyobb arányban fogadták el, hogy esetleg mégis tanárok lesznek. Drága és rossz hatékonyságú volt ez a túlzott létszámú tanárképzés.

Az új képzési struktúra kidolgozói arra törekedtek, hogy lehetőleg azok kerüljenek be a tanárképzésbe, akik valóban tanárok akarnak lenni. A diszciplináris alapokat pedig az alapképzésben tervezték biztosítani, gondoskodva arról is, hogy a diszciplináris felkészültség ne csorbuljon, mint ezt korábban kifejtettük. Létrejött tehát a bolognai rendszerként elhíresült felsőoktatási képzési struktúra és ezen belül a tanárképzés új rendje.

Ebben a rendszerben az alapképzést követően a tehetséges fiatalok sok nem tanári mesterszak közül választhatnak. Ezek a szakok piacképesebbek, tehát többen választják. A tanárszakra valóban csak azok jelentkeznek, akik tényleg tanárok akarnak lenni. Most vált láthatóvá tehát, hogy ha komolyan kell venni, akkor hányan választják a tanári pályát. Ez a bolognai-rendszernek nem hibája, hanem kívánatos sajátossága. Azt kell kiképezni tanárnak, aki az akar lenni! Ezzel a tudatosabb pályaorientációval reményeink szerint egyrészt a redukálódó kontraszelekció miatt, másrészt a motiváltabb hallgatói bázisnak köszönhetően, továbbá a tanári mesterség szaktudományon túli dimenzióinak mennyiségi és hitünk szerint minőségi emelésével a leendő tanárok hatékonysága fokozható, ami a presztízsproblémák mérséklésének egyik lépése lehet.

A jelenlegi viták gyökere nagyrészt a felsőoktatás átalakításának a tempójából is eredeztethetö. A bevezetésre - mind az alapképzés, mind a mesterképzés esetében - erőltetett tempóban került sor. Voltak ugyan szakmai viták, de feszítő gazdasági és politikai nyomások révén gyorsabban bevezetésre került, mintsem kiérlelödött volna a szakmai összhang. A nem megnyugtató társadalmi támogatás, a képzési piac beszükülése miatt kialakuló ellentétek tovább nehezítették a szakmai ütközések konszenzusra törekvő kezelését. A bevezetés előtti indokolt viták jelentős része így a bevezetés utánra tevődött. 
Mindemellett az első évek tapasztalatai megmutatták, és ez várható volt, hogy valódi hibái is vannak a bevezetett új rendszernek. A vitában így nemcsak álproblémák, hanem tényekkel alátámasztható ellenérvek is megjelentek. Az ütközési pontok számának, erejének köszönhetően a nyilvánosság számára egyre kiélezettebben adódott át a dilemmák, problémaértelmezések, kritikák többsége. A vita élesedése egyre nagyobb nyilvánosságot kapott. Az újságok hasábjain, a rádió és a televízió csatornáin egyre többen, egyre csípősebben, és egyre több tényszerü állítással bírálták a bolognai-rendszert, ami a már sokat említett presztízsnek egyáltalán nem kedvez. Szerencsés lenne ezt a folyamatot megállítani, építő jellegü megoldási tervekkel helyettesíteni.

A most már nyilvánvaló, valódi problémák kezelésére két élesen eltérő lehetőség kínálkozik.

Az egyik - és erre néhányan hajlanak - hogy a tanárképzést ki kell venni a bolognai-rendszerből, meg kell szüntetni az egységes tanárképzést. Ennek a megoldásnak a további részleteiről még nem sokat tudunk, de érezhetően a korábbi tanárképzés logikáját kívánják visszaállítani. Meglátásunk szerint ez részben lehetetlen, részben a kívánt kedvező változást sem érné el. Ha mégsem a korábbi struktúra reinkarnációját tervezik, akkor arra érdemes időt áldozni, nehogy a gyorsaság új, és a jelenleginél nem kisebb problémákat szüljön.

A másik lehetőség, hogy a tapasztalatok átgondolt értékelése alapján a szükséges változtatásokat a jelenlegi rendszer keretei között hajtjuk végre. Ennek legföbb feltétele, hogy a vita konstruktív vitává nemesedjen úgy, hogy a diszciplínák és pedagogikum képviselői elfogadva kölcsönös egymásrautaltságukat, félreteszik a presztízsféltést, a presztízssérelmeket, és a közös érdekeiknek megfelelően összefognak.

Ilyen szempontból örvendetes volt a Tanárképzők Szövetsége által szervezett vitafórum záró hangneme, amely az elkerülhetetlen együttmüködés mellett foglalt állást. Valójában jó esélye van a konstruktív kooperációnak, hiszen meggyőződésünk, hogy minden megnyilatkozó a maga hite szerinti legjobb tanárképzés mellett kötelezte el magát. A közismert nyertes-nyertes megoldásra kellene törekedni, és szerencsés lenne elfelejteni a nyertes-vesztes vita értelmességét.

Az együttmüködés első, és a megvalósulásáig a legfontosabb célkitüzése lehet, hogy elfogadtatjuk a társadalom felelős vezetőivel, ezen keresztül a társadalommal, hogy a fö problémát hazánkban a pedagógusok méltatlanul alacsony társadalmi elismertsége jelenti. Ha ezen nem sikerül jelentősen javítani, akkor nem tudunk áttörést elérni a kérdésben, bárhogy is alakítjuk át a képzés tartalmát, logikáját.

Amennyiben a jelenlegi kereteken belül keressük a jobb megoldásokat, előterjesztünk néhány konkrétabb javaslatot, amelyekben feltehetően könnyen egyetértenek a vitázó felek.

Egyik ilyen javaslat a második szak problémájára vonatkozik. Mint említettük, a második szak a szaktudományos felkészültségben különbözik az első szaktól. Tudjuk, hogy némely szakképzettség kizárólag második szakképzettségként értel- 
mezhető. Ezt a logikát javasoljuk némely esetben fordítva is alkalmazni. Azt javasoljuk tehát, hogy egyes szakterületeken csak úgy lehessen tanári szakképzettséget szerezni, ha a terület eléri, vagy legalább megközelíti a régi értelemben vett egyetemi szintű tanári képzettség szakterületi szintjét. Jelenleg ez plusz egy félévnyi, azaz 30 kredites többletet igényel a kétszakos képzésben, ahol nem másfél, hanem valódi kétszakos végzettséget kapnának a hallgatók. Két módja kínálkozik e törekvés megvalósításának. Egyrészt az alapképzésen belül, illetve az alap- és a mesterképzés közötti időben - államilag finanszírozott hallgató esetében állami finanszírozás mellett tehát a kredittúllépést megengedve - támogathatnánk ennek teljesítését. Az eddigi rendszer lényegében már biztosítja, hogy a 180 kreditet 8 félév alatt teljesítse a hallgató. Javaslatunk szerint ezt kibővítenénk úgy, hogy 8 félév alatt nem 180, hanem $210+10 \%$ kreditet finanszírozna az állam bizonyos szakterületeken. Elsösorban a tanárhiány miatt a természettudományos szakokat sorolhatjuk ide, de a klasszikus „bölcsész” szakterületeket sem lenne indokolt kizárni, mint pl. az idegen nyelvek, a magyar és a történelem. A tantárgyak körét mindenesetre pontosan meg kell határozni.

Második javaslatunk a szakok által élesen bírált 2 féléves kiegészítő képzésre vonatkozik. Nemcsak a szakterületek képviselőiben él a korábbi képzési logika, hanem azokban is, akik erre a képzésre felvételt nyernek. A magyar szakra bekerülők például Szombathelyen is meglepve tapasztalják, hogy a szak kurzusait csak néhány kreditnyi mértékben kell felvenni. Különösen azok szeretnének több szakmai tárgyat tanulni, akik régebben, pl. több mint 10 éve végeztek a föiskolán, és azóta tetemes pedagógiai, módszertani tapasztalatokra tettek szert, de szaktudományos felfrissülést szívesen fogadják. Javasoljuk, hogy a két félévet 3 félévre bővítsük, és a plusz félév (30 kredit) bővítse a szakterületi képzést. Igazolt, jelentős pedagógiai tapasztalat esetén az intézmény a pedagógiai gyakorlati kurzusok jelentős hányada alól felmentést is adhatna, így egyes esetekben a képzési idő nem is bövülne. Ez a változtatás ésszerüen rugalmasabbá tenné a képzési kereteket. Fenti logikával talán más sajátos képzési formák belső arányait is érdemes újragondolni!

Végül, de nem utolsó sorban egy általános problémát szeretnék hangsúlyozni, amiben feltehetően minden érintett egyetért.

Az alapképzések Képzési és Kimeneti Követelményei (KKK-i) akkor készültek, amikor még nem lehetett pontosan tudni a mesterképzések KKK-it. Sok oka volt összességében mindenkinek arra, hogy „túlzsúfolttá” tegye az alapszakot. Sokan vélekedünk úgy, hogy eljött az ideje az alapszakok felülvizsgálatának. A tanárképzés szempontjából ez valódi gondot jelent. A szakterületek ugyanis az alapszakon azt az elvet érvényesítették, hogy fel kell készíteni a hallgatót a diszciplináris mester szakra. Ezt nem tartják lehetségesnek 110 kredittel. Így azt a hallgatót, aki minden nehézség ellenére felveszi a második tanárszakhoz szükséges 50 kreditet, végképp nem tekintik megfelelően felkészültnek a diszciplináris mesterképzésre. Javaslatunk szerint az ilyen hallgató kapjon lehetőséget arra is, hogy a korábban 
ismertetett logika szerint a 8 félév finanszírozott féléven belül teljesíthessen külön térítés nélkül +30 kreditet az adott szakterületen.

A három javaslattal azt akartam érzékeltetni, hogy léteznek valódi problémák, amelyek megoldására jelentős többletforrás nélkül is lehet ajánlásokat megfogalmazni úgy, hogy az ne a szakterületek közötti rivalizációt jelentse, remélve, hogy az egymásra figyelő és építő módosítási tervek találkozásával a célnélküli és végtelennek tünő polémiák lezárhatóvá válnak. 